\title{
Kamppailua kunnista ja yliopistoista, juhlaa valtio-opissa
}

KATJA MÄKINEN MIIKA SALO

Koronavirusepidemian puhjettua alkuvuodesta 2020 poliittiset väittelyt loistivat poissaolollaan, kun huomio oli epidemian tuomassa uudessa tilanteessa. Epidemian pitkittyessä poliittinen keskustelu ja vastainasettelut ovat kuitenkin palanneet takaisin. Vapun alla koettu hallituskriisi ja oppositiopuolueiden kiistat EU:n elvytyspaketin hyväksymisestä eivät enää suoranaisesti liittyneet koronaepidemian kansalliseen hoitoon. Myös koronatoimenpiteet ovat herättäneet lisääntyvää debattia: esimerkiksi viime viikkoina tapahtuma-alaa koskevat rajoitukset ovat saaneet kritiikkiä myös hallituksen sisältä.

Kuntavaalit oli alun perin tarkoitus järjestää 18.4.2021, mutta eduskunta päätti maaliskuun lopulla siirtää vaaleja kesäkuulle huonontuneen tautitilanteen vuoksi. Kaikki eduskuntapuolueet perussuomalaisia lukuun ottamatta kannattivat kuntavaalien siirtoa. Päätös tehtiin oikeusministerin ja puoluesihteerien välisissä neuvotteluissa vain kuusi viikkoa ennen vaalipäivää. Vaikka vaalien siirto sinänsä hyväksyttiinkin laajasti, sen ajoitus keräsi arvostelua.

Mahdollisuus äänestää vaaleissa on keskeinen poliittinen oikeus. Niin vaalien järjestäminen pandemian keskellä kuin niiden siirtäminen voivat vaikuttaa äänestysaktiivisuuteen. Tästä syystä vaalien siirtäminen on merkittävä päätös, jonka tavoitteena täytyy olla kansalaisten poliittisen osallistuminen turvaaminen. Vaalien siirtoa perusteltiinkin juuri terveysturvallisuuden vaarantumisella (Oikeusministeriö 6.3.2021). Myös äänestysaktiivisuuden lasku nähtiin todellisena riskinä kun arveltiin ihmisten jäävän kotiin koronan pelossa. Kansalaisten keskinäisen tasa-arvon näkökulmasta erityisesti riskiryhmiin kuuluvat olisivat olleet epätasa-arvoisessa asemassa muihin nähden. (Emt.)

Koronapandemia on tarjonnut useissa maissa syyn kehittää uusia äänestämismuotoja perinteisten vaalikäytäntöjen rinnalle äänestäjien ja vaalivirkailijoiden terveyden turvaamiseksi (Asplund ym. 2020; Heinmaa 2020). Esimerkiksi Saksan Baijerissa käyttöönotettu postiäänestys nosti paikallisvaalien äänestysaktiivisuutta (Wolf 2020). Myös verkkoäänestyksen mahdollisuudet ja riskit on nostettu jälleen keskusteluun (emt.). Suomessa ennakkoäänestysaikaa on pidennetty kahteen viikkoon, ja ainakin osa kunnista mahdollistaa äänestäminen ulkotiloissa esimerkiksi autosta erikseen perustettavilla "drive-in"-äänestyspaikoilla (Lapintie 15.4.2021). Uusien vaalikäytäntöjen vakiinnuttaminen ja jatkuva kehittäminen parantavat vaalien saavutettavuutta eri ihmisryhmille myös tulevaisuudessa väestön ikääntyessä.

Koronaepidemia on heijastunut vahvasti vaalikampanjointiin, ja tänä vuonna toreilla ja kaduilla on nähty selvästi tavallista vähemmän perinteisiä vaalimökkejä ja esitteitään jakavia ehdokkaita. Tämä korostaa muun näkyvyyden ja aiemman tunnettavuuden merkitystä. Tilanne palvelee niitä, joilla on mahdollisuuksia ostaa mainostilaa tai jotka ovat jo muuten tunnettuja alueillaan, vaikka demokratiassa kaikilla tulisi olla yhdenvertainen mahdollisuus poliittiseen osallistumiseen yhteiskunnallisesta asemasta ja taustasta riippumatta. Sosiaalinen media tarjoaa parhaimmillaan hyvinkin edullisen tavan tuoda esiin omia näkemyksiä ja käydä keskustelua 
potentiaalisten äänestäjien kanssa. Vaalikampanjoinnin siirtyminen lähes kokonaan verkkoon ei kuitenkaan takaa yhdenvertaisia osallistumismahdollisuuksia, vaan voi hyödyttää kokeneita sosiaalisen median käyttäjiä, joilla on hallussaan virtuaalisen kampanjan rakentamiseen tarvittava tietotaito ja seuraajapohja. Samalla sosiaalisen median mahdollistama aggressiivinen ilmaisu ja vihapuhe voivat myös lannistaa halua osallistua keskusteluun ja asettua kuntavaaliehdokkaaksi (Knuutila ym. 2019).

Kuntavaalien yhteydessä on muistettava, että Manner-Suomessa käydään samanaikaisesti 293 vaalit hyvin erikokoisissa ja -näköisissä kunnissa. Pienemmissä kunnissa valtuustojen ovet voivat avautua ilman kampanjaakin, kun taas suurimmissa kaupungeissa ehdokkaiden täytyy käyttää yleensä jonkin verran rahaa ja aikaa varmistaakseen läpimenonsa. Esimerkiksi edellisvaaleissa yli puolet Helsingissä ehdokkaina olleista kulutti kampanjointiinsa yli 800 euroa - ja yli neljännes käytti kampanjointiinsa 21-40 tuntia viikossa viimeisinä neljänä viikkona ennen vaalipäivää. Vastaavat luvut pienenevät mitä pienemmästä kunnasta puhutaan. (Kestilä-Kekkonen ym. 2018, 32-34.) Toisin sanoen pienemmissä kunnissa valtuustoon voi päästä hyvinkin matalalla kynnyksellä, kun taas pääkaupunkiseudulla kampanjointi vaatii jo puoliammatillista otetta.

Demokratian optimaalisen toteutumisen vuoksi olisi tärkeää, että eri ihmisryhmät äänestäisivät yhtä paljon. Näin ihmisten elämäntilanteiden ja näkemyksien kirjo välittyisi poliittiseen päätöksentekoon. Artikkelissaan "Poliittinen osallistuminen osana kotoutumista. Maahan muuttaneiden äänestysaktiivisuus vuoden 2017 kuntavaaleissa" Josefina Sipinen tutkii Suomeen muuttaneiden venäläis-, virolais-, somalialais- ja ruotsalaistaustaisten äänestysaktiivisuutta ja siihen vaikuttavia sosiaalisen taustan eri tekijöitä. Artikkeli perustuu sähköiseen äänestysrekisteriin ja siihen yhdistettyihin sosioekonomisiin tietoihin. Tulokset osoittavat, että maahan muuttaneiden äänestysaktiivisuus on keskimäärin alhaisempi kuin suomalaistaustaisten. Maahan muuttaneiden keskuudessa turvattu yhteiskunnallinen asema nosti äänestämisen todennäköisyyttä kaikissa muissa ryhmissä paitsi somalialaistaustaisilla, jotka äänestivät aktiivisesti muita heikommasta sosioekonomisesta asemastaan huolimatta.

Kuudessa suomalaiskunnassa kuntavaalikampanjointia värittää pormestarin valinta. Vaikka pormestaria ei valitakaan suoralla kansanvaalilla, uusi pormestari nousee tavallisesti eniten ääniä saaneesta puolueesta. Esimerkiksi Helsingissä ja Tampereella kuntavaaleja saatetaan suoranaisesti tituleerata "pormestarivaaleiksi", sillä useat puolueet ovat asettaneet pormestariehdokkaikseen nimekkäitä politiikkoja, jotka toimivat eräänlaisina vaalivankkureina koko puolueelle. Pormestarin rooliin liittyviä käsityksiä tarkastellaan Anni Jäntin, Arto Haverin ja Jenni Airaksisen artikkelissa "Pormestarimalli kuntajohtamisen muotona. Pormestarimalliin liittyvät tavoitteet, odotukset ja uskomukset". Artikkelissa analysoidaan millaisin argumentein pormestarimallia kannatetaan tai vastustetaan Ylen ja Helsingin Sanomien verkkosivuilla julkaistuissa uutisartikkelissa. Pormestarimallissa ei aineiston perusteella ole kyse pelkästään kunnan johtohahmosta, vaan malli kytketään kuntajohtamisen laajempiin kysymyksiin. Sillä uskotaan olevan seurauksia demokratialle, johtamiselle, kunnan ja kuntalaisten väliselle suhteelle sekä poliittisen ja virkajohdon väliselle suhteelle. Kirjoittajat tunnistavat neljä väittämäparia, jotka tiivistävät pormestarimalliin yleisimmin liitettäviä käsityksiä.

Kolmas artikkeli osallistuu ajankohtaiseen keskusteluun yliopistodemokratiasta. Yliopistojen hallinnollisen autonomian ja kolmikantaisen yliopistodemokratian arviointi on kirjattu 
pääministeri Marinin hallituksen ohjelmaan. Opetus- ja kulttuuriministeriön asettama arviointiryhmä luovutti selvityksensä opetus- ja kulttuuriministeriölle 1. maaliskuuta 2021. Hanna Kuuselan, Veera Kalevan, Tuukka Tomperin, Mikko Poutasen ja Tuomas Tervasmäen artikkeli "Korkeakoulupolitiikan muuttuvat valtasuhteet Suomessa. Säätiöyliopiston synty ja kamppailu yliopistodemokratiasta” tarkastelee poliittis-lainsäädännöllistä prosessia, joka johti yliopistolain uudistamiseen vuonna 2009 sekä säätiöyliopistomallin synnyttämiseen. Kirjoittajat muodostavat asiakirja-aineiston pohjalta konjunktuurillisen rekonstruktion, joka osoittaa, että prosessissa valtion, elinkeinoelämän ja yliopistojen ylimmän johdon intressit kohtasivat. Niiden keskinäisten suhteiden lähentyminen mahdollisti demokraattisesti järjestäytyneiden yliopistoyhteisöjen marginalisoinnin ja osittain myös eduskunnan tavanomaisen lainsäädäntötyön sivuuttamisen. Tämä muutos yliopistokentän valtasuhteissa heikensi merkittävästi yliopistodemokratiaa ja yliopistoyhteisöjen asemaa Suomessa.

Keskustelua-osiossa kuntavaalien äänestysaktiivisuus nousee käsittelyyn myös toisesta näkökulmasta. Jussi Westinen tarkastelee äänestysaktiivisuuden maantieteellistä vaihtelua artikkelissaan "Kunta- ja eduskuntavaalien äänestysaktiivisuus kuntakoon mukaan". Kuntavaaleissa äänestysaktiivisuus on ollut pääsääntöisesti korkeampi pienemmissä kunnissa, mutta vuoden 2017 vaaleissa erot tasoittuivat. Eduskuntavaaleissa kuntakoon merkitys äänestysaktiivisuuteen on ollut vähäisempi. Äänestysaktiivisuuden nousu oli sekä vuoden 2017 kuntavaaleissa että vuoden 2019 eduskuntavaaleissa erityisen vahvaa suurimmissa kaupungeissa. Tätä selittää osittain se, että suurten kaupunkien väestöllä on korkeampi koulutus ja matalampi työttömyys, jotka ovat äänestysalttiutta nostavia tekijöitä. Myös mediajulkisuus suosii suurten kaupunkien ehdokkaita ja asioita. Äänestysprosentin noususta huolimatta viiden suosituimman ehdokkaan osuus kaikista äänistä on kasvanut kaikissa suurimmissa kaupungeissa. Erot suurimpien kaupunkien eri äänestysalueiden äänestysaktiivisuudessa ovat erittäin suuria. Korkean tulo- ja koulutustason alueilla äänestetään huono-osaisia alueita aktiivisemmin, joskin vuoden 2017 kuntavaaleissa äänestysaktiivisuus nousi myös monilla sellaisilla alueilla, joiden sosioekonomisen status on matala.

Kesällä 2021 valtio-oppi yliopistollisena tieteenalana Suomessa täyttää 100 vuotta. Vuonna 1921 Helsingin yliopistoon perustettiin valtio-opin oppiaine, joskin Turun akatemiaan oli perustettu jo vuonna 1640 historian ja valtio-opin professuuri. Pertti Ahosen katsausartikkeli "Hegemonia Suomen valtio-opissa 1921-2021" tarjoaa katsauksen valtio-oppiin koko satavuotiskaudella. Valtio-opin professoreiden tutkimustyötä paikannetaan katsauksessa tieteenfilosofisten taustaolettamusten perusteella. Kiinnittäen huomiota tiedon ja havaitsemisen suhteeseen sekä tiedonmuodostajan ja tiedonmuodostuksen kohteen suhteeseen professoreiden tutkimus jaetaan behavioraaliseen, rationalistiseen, kriittis-realistiseen ja refleksiiviseen kategoriaan, joista viimeinen jakautuu interpretivistiseen, ei-foundationaaliseen ja jälkifoundationaaliseen. Luokittelu osoittaa, että Suomessa valtio-opin tieteenalalle ei ole muodostunut hegemonista keskusta, mutta yliopistokohtaisia hegemonioita on havaittavissa.

Erkki Berndtson arvioi Jukka Kortin kirjoittaman Helsingin yliopiston valtiotieteellisen tiedekunnan tilaaman 75-vuotishistoriikin Valtaan ja vastavirtaan. Tiedekunnan oppiainevalikoima on vaihdellut vuosikymmenten varrella, mutta valtio-oppi on kuulunut siihen alusta asti. Kirjassa käydään läpi tiedekunnan vaiheita ja roolia suomalaisen hyvinvointivaltion ja yhteiskunnan rakentamisessa, yliopistoradikalismissa ja yliopistohallinnonuudistustaistelussa yleisen 
ja yhtäläisen äänioikeuden puolesta. Nykyvaihetta määrittävät historiikin mukaan talous ja tulosjohtaminen, ja Berndtson viittaakin myös yliopistodemokratian purkamiseen rakenteellisten muutosten seurauksena. Nykytilanteessa huomiota saavat lisäksi uusien oppiaineiden ja opintokokonaisuuksien synty, virkarakenteen muuttaminen, uudenlainen opetukseen panostaminen, kansainvälistyminen sekä tasa-arvokysymykset.

Suomalaisen valtio-opin satavuotisjuhlan kunniaksi nostamme sosiaalisessa mediassa loppuvuoden aikana arkistoista esiin Politiikka-lehdessä aiemmin ilmestyneitä kirjoituksia. Politiikka-lehden toimitus osallistui toukokuun alkupuolella juhlavuoden Politiikan tutkimuksen päiville ja on jatkossakin mukana Valtiotieteellisen yhdistyksen syntymäpäiväjuhlinnassa. Kannattaa siis seurata sekä lehden että yhdistyksen verkkosivuja. Lehti juhlistaa merkkivuotta myös syksyllä järjestettävällä muistelutilaisuudella, joka pyrkii tuomaan saman pöydän - tai ainakin "saman ruudun" ääreen - eri aikakausien politologisukupolvia ympäri maan. Merkkipaalu on hyvä hetki pysähtyä miettimään, voisiko Politiikka toimia entistä aktiivisemmin, yhteisöllisemmin ja vuorovaikutteisemmin. Toimitukselle voi aina lähettää ideoita ja toiveita lehden sisällöstä ja rooleista tiedeyhteisössämme niin sähköpostilla kuin sosiaalisessa mediassa.

\section{LÄHTEET}

Asplund, Erik, Stevense, Bor, James, Toby ja Clark, Alistair. 2020. Elections need to be accessible for the ill during COVID-19 to avoid disenfranchisement. International IDEA. https://www.idea.int/newsmedia/news/elections-need-be-accessible-ill-during-covid-19-avoid-disenfranchisement. Viitattu 21.5.2021.

Heinmaa, Anika Eeleni. 2020. Special Voting Arrangements (SVAs) in Europe: In-Country Postal, Early, Mobile and Proxy Arrangements in Individual Countries. International IDEA. https://www.idea. $\mathrm{int} /$ news-media/news/special-voting-arrangements-svas-europe-country-postal-early-mobile-andproxy. Viitattu 21.5.2021.

Kestilä-Kekkonen, Elina, Sipinen, Josefina, Borg, Sami, Tiihonen, Aino ja Wass, Hanna. 2018. Kuntademokratiaindikaattorit 2017. Helsinki: Oikeusministeriö.

Knuutila, Aleksi, Kosonen, Heidi, Saresma, Tuija, Haara, Paula ja Pöyhtäri, Reeta (2019) Viha vallassa. Vihapuheen vaikutukset yhteiskunnalliseen päätöksentekoon. Valtioneuvoston selvitys- ja tutkimustoiminnan julkaisusarja 2019:57. Helsinki: Valtioneuvoston kanslia. http://urn.fi/ URN:ISBN:978-952-287-786-4. Viitattu 21.5.2021.

Lapintie, Lasse. 15.4.2021. Kuntavaaleissa voi ensi kertaa äänestää autosta - oikeusministeriö julkaisi ohjeet turvalliseen äänestämiseen. Helsingin Sanomat. https://www.hs.fi/politiikka/art2000007921166.html. Viitattu 24.5.2021.

Oikeusministeriö. 6.3.2021. Kuntavaalit siirtyvät kesäkuulle. Tiedote. https://oikeusministerio.fi/-/ kuntavaalit-siirtyvat-kesakuulle. Viitattu 24.5.2021.

Wolf, Peter. 2020. The COVID-19 crisis - A much needed new opportunity for online voting? International IDEA. https://www.idea.int/news-media/news/covid-19-crisis---much-needed-new-opportunity-online-voting. Viitattu 21.5.2021. 